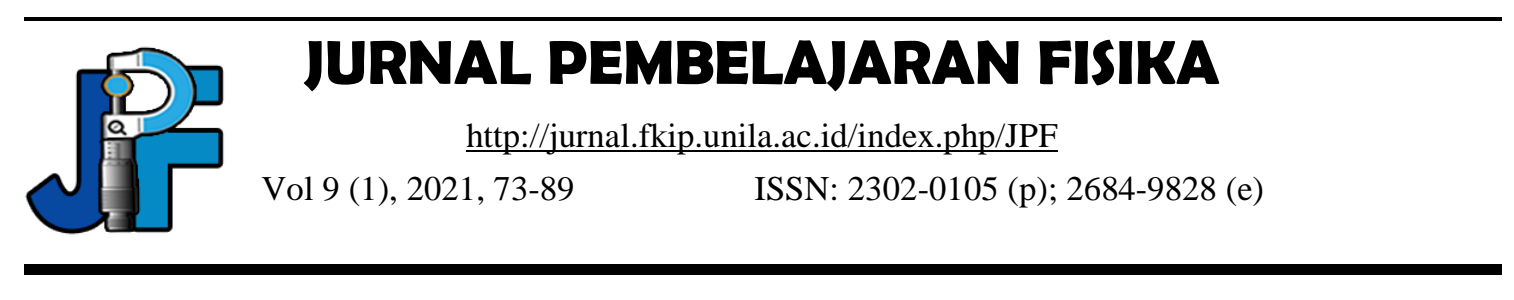

\title{
The Development of Discovery Learning-based Module to Improve Students' Scientific Literacy
}

\author{
Indah Slamet Budiarti, Triwiyono Triwiyono, Florentina Maria Panda \\ Physics Education Study Program, Education and Teacher Training Faculty, Universitas Cenderawasih, \\ Jayapura, Papua, Indonesia \\ *e-mail: indah_budiarti@yahoo.com
}

Received: Juni 21, 2021

Accepted: July 18, 2021

Published: July 19, 2021

\begin{abstract}
In learning science, it is necessary to have a learning model that can integrate scientific literacy skills. This study aimed to develop discovery learning-based module to improve students' scientific literacy. We used R \& D research that adapts the 4-D model device development procedure, namely define, design, develop, and disseminate. Product assessment was carried out after revision stage I by 3 media experts, 3 material experts, and 1 SMA YPPK Taruna Bakti teacher. To determine student responses, the product was tested for feasibility and readability on $5 \mathrm{X}$ grade students of SMA YPPK Taruna Bakti through a limited trial. The product was revised and tested again through a broad trial on 16 students. The revision through experts' comments and students' initial responses has affected the readability, feasibility, and usability of developed Newton's Law module. There were no students who have high scientific literacy. Students who have low scientific literacy were 13 and students who have moderate scientific literacy were 3 . It can be said that the module cannot significantly improve students' scientific literacy because of online learning environment.
\end{abstract}

Keywords: Discovery learning, Modul, Newton's Law, Scientific literacy

DOI: http://dx.doi.org/10.23960/jpf.v9.n1.202107 


\section{INTRODUCTION}

At the beginning of 2020, Indonesia was hit by cases of Coronavirus Disease (Covid-19) (Bai et al., 2020). It causes all forms of activity to be online, one of which was in the field of education (Fitriyani, Fauzi, \& Sari, 2020). This resulted in the learning process required to study at home, namely in the form of online learning (in the network). Online learning is a distance education system that uses a set of teaching methods, namely there are teaching activities that are held separately from learning activities (Fajrillah et al., 2020). Other research explains that online learning must use the internet network with accessibility, connectivity, flexibility, and the ability to bring up various types of communication in learning (Sadikin \& Hamidah, 2020). Based on these studies, it can be concluded that online learning is online learning using digital devices such as mobile phones, laptops, or computers, and internet networks.

As a result of this pandemic, the Ministry of Education and Culture of the Government stated that universities were not allowed to carry out face-to-face (conventional) learning and ordered them to carry out online learning ( $\mathrm{Li}$, Ye, Tang, Zhou, \& $\mathrm{Hu}, 2018)$. Based on this, Indonesia implemented a new order to adapt to Covid-19, including a new order in the field of education (Buheji \& Buheji, 2020). The new order in the field of education makes educators and students must be able to be adaptive in the learning that will be applied (Basu, Biswas, \& Kinnebrew, 2017). The learning applied during this pandemic makes students have to learn a lot independently. One of the important things to get the attention of students in managing learning activities independently is the use of teaching materials (Naimah, Winarni, \& Widiyawati, 2019). The 2013 curriculum demands that teachers act as facilitators, motivators, and alternative learning resources (Permendikbud, 2016).

Physics is a branch of science that studies natural phenomena through a series of scientific processes by a scientific attitude (Serway \& Jewett, 1998). The results are expressed in the form of scientific products composed of important components in the form of facts, concepts, generalizations, principles, theories, and physical laws that are universally applicable (Mustari \& Sari, 2017). One of the materials in physics learning is material about Newton's Laws. The material is closely related to everyday human life. Students are very focused on the questions given, without further understanding their application in everyday life (Trianggono, 2017). Students need the ability to use scientific knowledge so that they can define problems to make decisions. It is called scientific literacy (OECD, 2016). But in fact, until now the scientific literacy ability of students is still very low. It can be seen by the results of several studies, stating that students' scientific literacy skills are still relatively low (Hadi, Munawaroh, Rosidi, \& Wardani, 2020; Dhewa, Rosidin, Abdurrahman, \& Suyatna, 2017; Sudarmin, Mursiti, \& Asih, 2018). Scientific literacy is the ability to use scientific knowledge, identify questions, and draw conclusions based on evidence, to understand and make decisions regarding nature and changes made to nature through human activities (OECD et al., 2004). Doing science learning can be one way to improve scientific literacy.

In learning science, it is necessary to have a learning model that can integrate scientific literacy skills (Saputra, Al Auwal, \& Mustika, 2017). One suitable learning model is the discovery learning model (Rahayu, Rumahorbo, \& Wahyudi, 2020). The discovery learning model was first proposed by Jerome Bruner in 1915 (Hadi et al., 
2020). The discovery learning model is a model that emphasizes understanding the structure or important ideas of a discipline, through the involvement of students being active in the learning process (Indarti, 2019). The discovery learning model proposes teachers to give students the freedom to find something on their own (Wartono, Batlolona, \& Mahfi, 2019). Students will arrive at an experience and help students express their ideas together and improve understanding when given assignments or conducting experiments (Abou Faour \& Ayoubi, 2017).

Currently, education is still affected by the pandemic and requires online learning, so that the implementation of the learning model is not carried out optimally (Maryam, 2021; Schuchter, 2021). Therefore, students need facilities and infrastructure that can help students learn with the right learning model during the learning process (Risdianto, Dinissjah, \& Nirwana, 2020). One of the facilities and infrastructure needed is the existence of an e-book, which is a combination of print technology with computer technology in learning activities (Kurniawan, Jufrida, Basuki, Ariani, \& Fitaloka, 2019). One of which is a module that is presented in electronic form (e-module) (Çelik et al., 2018). A module is a teaching material that is systematically designed based on a certain curriculum and packaged in the form of the smallest learning unit and allows it to be studied independently in a certain time unit (Annisa, Lesmono, \& Yushardi, 2020; Hartini, Firdausi, Misbah, \& Sulaeman, 2018).

Electronic modules (e-modules) are a form of presenting independent teaching materials that are systematically arranged into certain learning units that are presented in an electronic format (Thaoge, 2021). It includes animation, audio, navigation that makes users more interactive (Indra, Astuti, \& Mering, 2021). The electronic module in its writing structure adapts the format, characteristics, and parts contained in the print module in general, but there are differences in the presentation only (Rosanna, Yerimadesi, \& Oktavia, 2021). The proper module contains models, methods, materials, limitations of learning materials, instructions for learning activities, exercises, and ways to evaluate, which are designed systematically and in communicative and interesting language to achieve the expected competencies and can be used independently (Amar, Suranto, \& Sajidan, 2020; Sohn \& Yoon, 2010).

Based on this, the researcher conducted a study to produce a product in the form of a science e-module with Newton's Law material based on the discovery learning model to be able to improve students' scientific literacy skills. The purpose of our research was to design a discovery learning-based module to improve scientific literacy skills in Newton's Law material and test the quality to get student responses in class X SMA YPPK Taruna Bakti. Our research question is "How to do develop e-module based on discovery learning to improve students' scientific literacy?". We developed the module starting from design. Then, we analyzed the quality based on experts' perspective and students' responses to discovery learning-based modules to improve scientific literacy skills in the Newton's Law material.

\section{METHOD}

Research and development methods, or is often called Research and Development ( $R \& D$ ), is a research method used to produce certain products, and test the effectiveness of these products (Buchori \& Setyawati, 2015). The product developed in this research was teaching materials in the form of modules as teaching materials for 
science learning for class X students of SMA YPPK Taruna Bakti material Newton's Law. The method in this research was divided into research design and procedures, population and samples, data collection and instrument, and data analysis.

\section{Research Design \& Procedures}

This research is a procedural $\mathrm{R} \& \mathrm{D}$ research that adapts the 4-D model device development procedure, namely define, design, develop, and disseminate (Sugiyono, 2010). This research was carried out until the development stage only because dissemination could not be carried out widely due to regional restrictions in Jayapura as a government regulation during the pandemic (Kompas, 2020). The definition stage is the initial stage of research on the development of this module. The purpose of this stage is to determine and define the learning requirements. In this stage, it is necessary to determine the learning needs used, the characteristics of students, the material presented, and the objectives and competencies to be achieved by students (Amar et al., 2020). Needs analysis aims to emerge and determine the basic problems faced by learning (Trianto, 2014). Needs analysis begins with making observations at SMA YPPK Taruna Bakti by paying attention to and analyzing aspects of studenst characteristics, textbooks or reference books used, and learning materials.

Product assessment is an assessment stage that is carried out after revision stage I. The assessment is carried out by 3 media experts, 3 material experts, and 1 YPPK Taruna Bakti high school teacher. If there are suggestions and input from the assessment team, they are used as guidelines for revision I. At this stage, trials are carried out on the products developed. The product trial consists of 2 stages, namely a limited trial (initial testing) and a broad trial (quantitative testing). The limited and broad trial phase were carried out on five SMA YPPK Taruna Bakti students. The research procedure in this study can be seen in Figure 1.

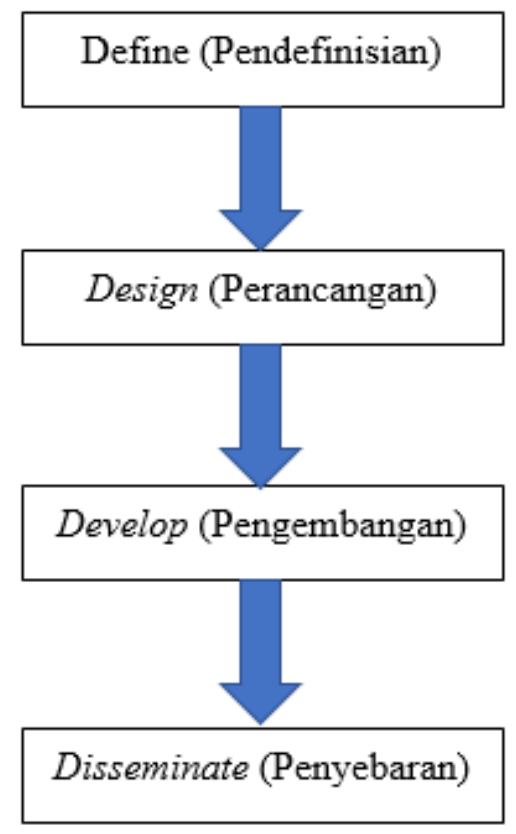

Figure 1. Research Procedure Using 4D Model 


\section{Population and Sample}

The trial will be carried out with 2 stages of testing, namely limited trials and extensive trials. Limited trials and extensive trials were conducted with the research population which were class $\mathrm{X}$ students as respondents. The subjects of this study as samples included 1 instrument validator, 6 product validators, 3 media appraisers, 3 material expert appraisers, and 1 YPPK Taruna Bakti high school teacher. To determine student responses, the product was tested for feasibility and readability on $5 \mathrm{X}$ grade students of SMA YPPK Taruna Bakti through a small or limited scale trial. After that, the product was revised and tested again through a wide-scale trial on 16 students. The sampling technique used was purposive sampling because we intended to elaborate the revision of module from experts and pratitioners.

\section{Data Collection and Instrument}

The data obtained are qualitative data and quantitative data. Qualitative data obtained from the assessment of media experts using a likert scale with a response scale of four, namely: very good; good; not good; very bad. Quantitative data were also obtained from the assessment of students or practitioners who used the assessment parameters (very good, good, not good, very bad) in the preliminary field test while the assessment score was agree and disagree on the main field test. The other qualitative data were obtained from observation sheets to be filled out by the physics teacher at the main field test stage. Quantitative data is obtained by giving a score to each assessment item from qualitative data. This quantitative data is processed to obtain information on the quality and implementation of the developed modules (Hall \& Steiner, 2020).

The observation instrument used was in the form of an interview sheet to the science teacher of the school understudy (Rianti, Akhsan, \& Ismet, 2020). This interview sheet contains questions that lead researchers to the problems and needs of the school being studied, so that research can be carried out that can solve problems at the school. The evaluation or assessment instrument used is in the form of a questionnaire to test or assess the product development of this practicum tool. The questionnaire uses a four-choice Likert scale model which is made in the form of a checklist. The selection of a response scale of four aims so that the instrument can reveal more maximally the differences in respondents' attitudes. The data collection instruments used were instrument validator questionnaire sheets and product quality assessment questionnaire sheets. The questionnaires were tested through general validation before test.

\section{Data Analysis}

This study uses descriptive data analysis and the process of developing Discovery Learning-based modules to improve the scientific literacy of SMA YPPK Taruna Bakti students in the form of qualitative descriptive data with development procedures. The data obtained were then collected and analyzed. There are two types of data analyzed, namely data on the quality level of the module and data on student responses. The module quality level data is analyzed to determine the module quality assessment, the assessment of material experts, media experts, and teachers is carried out based on input data in the form of an assessment sheet using a likert scale then 
changed from quantitative to qualitative form. Table 1 is the likert scale on module quality assessment that is used to the expertise's perspective.

Table 1. Likert Scale on Module Quality Assessment

\begin{tabular}{cc}
\hline Skor & Criteria \\
\hline 4 & Very Good \\
3 & Good \\
2 & Less \\
1 & Very Less \\
\hline
\end{tabular}

The data obtained through a questionnaire to determine the assessment of the quality of the module which is the assessment of material experts, media experts and science teachers, is carried out based on input data in the form of an assessment sheet using a Likert scale with a score of 1 to 4 . The use of an even number of scores to eliminate the middle value. This type of middle answer has a double meaning, it cannot give an answer, neutral or doubtful. Because categories that have multiple meanings are not expected in the instrument. In addition, the data obtained from the student response questionnaires were then analyzed by changing the response categories into scores using the gutman scale with the provisions in Table 2.

Table 2. Score Conversion to the Gutman Scale Skala

\begin{tabular}{ccc}
\hline \multirow{2}{*}{ Category } & \multicolumn{2}{c}{ Score } \\
\cline { 2 - 3 } & Positive & Negative \\
\hline Agree & 1 & 0 \\
Disagree & 0 & 1 \\
\hline
\end{tabular}

Next, the researcher calculates the average score of each aspect that is responded to and changes the average score obtained into qualitative form based on Table 2 . Qualitative criteria are determined by first looking for the interval between levels strongly agree to strongly disagree using the formula as shown in Table 3 . The formula of score conversion criteria is based on (Medvedev et al., 2017).

Table 3. Students' Responses Criteria

\begin{tabular}{cc}
\hline Mean Score & Criteria \\
\hline$>0.5 \mathrm{~s} / \mathrm{d} 1$ & Agree \\
$0 \mathrm{~s} / \mathrm{d} 0.5$ & Disagree \\
\hline
\end{tabular}

After obtaining the results of the pretest and posttest classes given the provision of modules in learning, then the normalized gain value (n-gain) was calculated to see the increase in students' mastery of concepts of Newton's Law. The n-gain test was done to analyze whether the electronic module has improved the students' scientific literacy at online learning during covid-19 pandemic in Jayapura. N-gain is determined after the broad testing of Newton's Law electronic module using Equation 1.

$N-$ gain $=\frac{\text { posttest score }- \text { pretest score }}{\text { maximum score }- \text { pretest score }}$ 
The improvement of student's scientific literacy is categorized as high if the ngain score is $\mathrm{G}>0.7$. The improvement of student's scientific literacy is categorized as moderate if the n-gain score is $0.3 \leq \mathrm{G} \leq 0.7$. The improvement of student's scientific literacy is categorized as high if the $n$-gain score is $G<0.3$. The $n$-gain score is expected to indicator showing that students have improvement in their scientific literacy after using electronic module of Newton's Law that has been developed.

\section{RESULT AND DISCUSSION}

\section{Results on Initial Stage of Product Development}

The initial product of this research is a physics module based on the discovery learning model for SMA/MA class X on Newton's Law material. The presentation and content of this module are adapted to the development of SMA/MA students. Newton's Law material presented in the module is by core competencies and basic competencies. The core competencies for the SMA/MA level are understanding knowledge (factual, conceptual, and procedural) based on students' curiosity about science, technology, art, culture related to visible phenomena and events and processing, presenting in the concrete realm (using, parsing, assembling, modifying, and creating). Students have to understand abstract realms (writing, reading, counting, drawing, and composing) according to what is learned in school and other sources in the same perspective/view/theory. The basic competencies for SMA/MA level are as follows: (3.2) Analyzing straight motion and the effect of force on motion based on Newton's Laws and its application to the motion of objects and the motion of living things; (4.11) Presenting the results of the investigation of the effect of force on the motion of objects.

The preparation of the initial product of the physics module based on science literacy skills includes several sections including the opening, content, and closing sections. The opening section consists of the front page of the module, introduction, table of contents, introduction, module presentation, and concept map. Figure 1 shows the cover of module and the concept map of Newton's law.

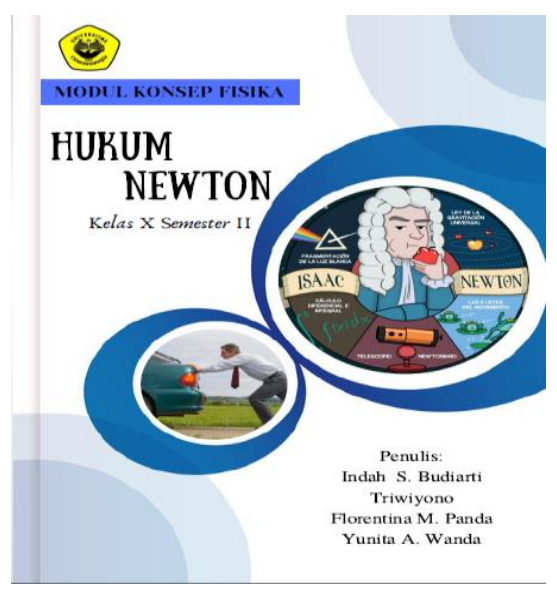

(a)

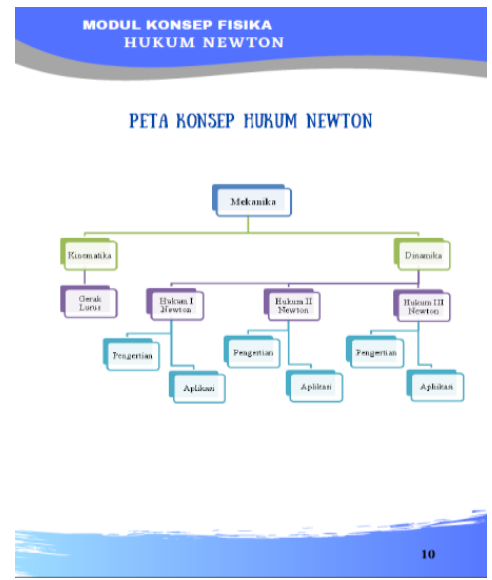

(b)

Figure 2. (a) Cover of Module and (b) Concept Map of Newton's Law 
This module material is divided into 3 meetings, namely meeting 1 Newton's First Law, meeting 2 Newton's Second Law, and Meeting 3 Newton's Third Law. The next content is the discovery learning stage according to the syntax of the discovery learning model. There are stimulation stages, problem statements, data collecting, data processing, data verification, and generalization. Figure 2 shows the content of activity in the module and data collecting stage of discovery learning.

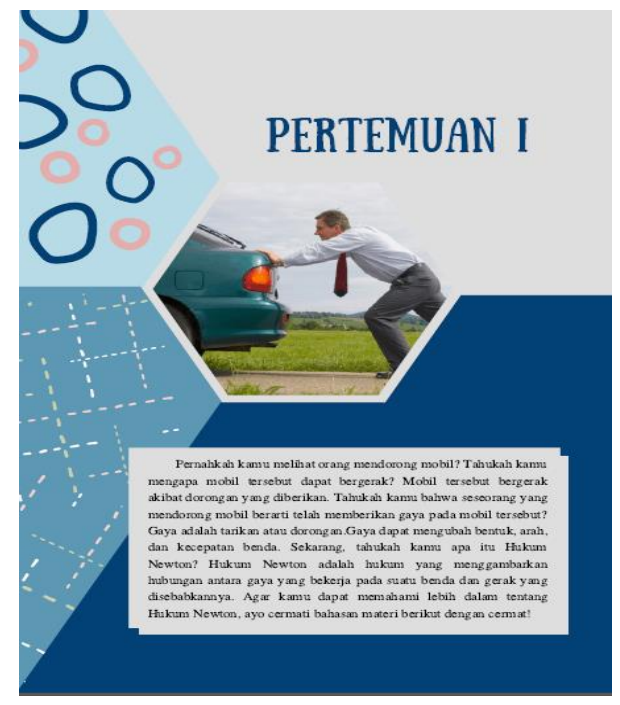

(a)

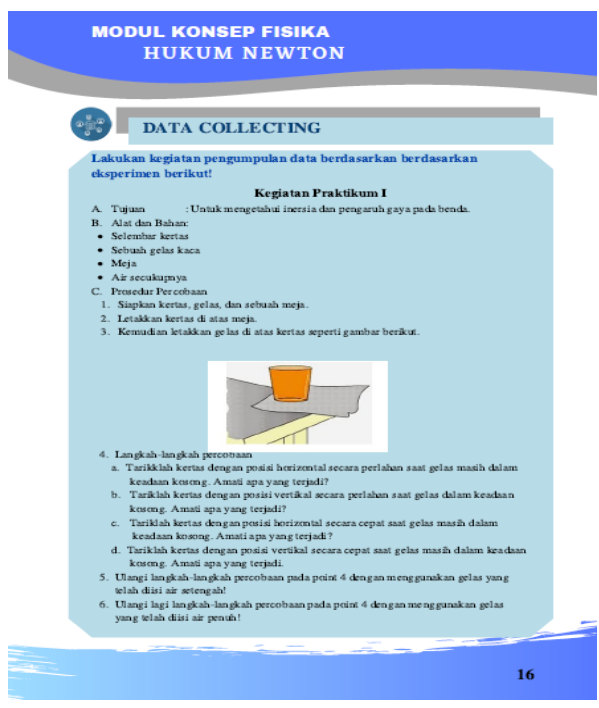

(b)

Figure 3. (a) Content of Activity in the Module and (b) Data Collecting

Next, there are examples of questions that are equipped with solutions. There are also practice questions that students can do. The closing section of the module contains a summary of the meeting material for Newton's First Law, Newton's Second Law, and Newton's Third Law. The bibliography contains a list of references from the literature used by the author in compiling the module. This glossary includes definitions of various terms in the science process skills-based science module which aims to help readers find the definition of terms in the description of material information.

\section{Instrument and Product Validation}

The validation used is instrument validation and product validation. Instrument validation is carried out by 1 validator and product validation is carried out by 4 validators, namely 2 material experts and 2 media experts. Validator 1 states that the presentation of sentence editorials on achievement indicators needs to be adjusted to learning outcomes and operational verbs. The presentation of concept maps needs to be adjusted to the physical meaning (full explanation is in the draft). Evaluation presentations should avoid statements that are too long because the representation of students in the class varies. Picture descriptions should directly refer to the activities carried out / the intended concept. The working steps of the model used based on scientific literacy must be written in a draft to make it easier for the author to describe each step into theory during the learning process. Table 1 shows the recapitulation of validation process from experts. 
Table 4. Validation from Experts

\begin{tabular}{ccc}
\hline No & \multicolumn{1}{c}{ Statements } & \multicolumn{1}{c}{ Status } \\
\hline 1 & $\begin{array}{l}\text { Sentence editorial presentation on achievement indicators } \\
\text { needs to be adjusted to learning outcomes and operational } \\
\text { verbs. }\end{array}$ & Revision is required \\
2 & $\begin{array}{l}\text { The presentation of the concept map needs to be adjusted } \\
\text { to the physical meaning (full description is in the draft). } \\
\text { The presentation of experimental activities may need to } \\
\text { be changed from passive to active in order to train } \\
\text { students' scientific literacy. }\end{array}$ & Revision is not required \\
The evaluation presentation should avoid statements that \\
are too long because the representation of students in the \\
class varies. \\
The description of the picture should directly refer to the \\
activities carried out/the intended concept. \\
The working steps of the model used based on scientific \\
literacy must be actually written in a draft (preferably \\
understanding the operational definition of each step) to \\
make it easier for the author to describe each step into the \\
material.
\end{tabular}

Before the module is assessed by material experts, media experts, and physics teachers, the module should become a suitable product for students to use. The physics learning module based on the discovery learning model on Newton's Law material is validated first by 4 validators, namely 2 material expert validators and 2 media expert validators. The criticisms and suggestions from the product validator are that the presentation of images must be representative, meaning that the images presented represent and help the information needed by students. The images displayed must be chosen in such a way that they can provide general form and function. The descriptions on the images must represent sentences. Shortly, we had been pouring out the information and thoughts the author wants. The source of the image must be included and the video display is very representative. Thus, the module can be easily understood.

\section{Product Assessment}

The purpose of this product assessment is to determine the quality of the product developed based on the assessment of experts and high school physics teachers. In addition to assessing the product to find out whether or not the product has been revised, the experts also provide corrections and improvements so that errors and deficiencies in the module can be corrected and refined. Then the criticisms and suggestions given by the assessor are used as material for revision II. The product assessment was carried out by 2 material experts, 2 media experts, and 1 high school/science physics teacher.

Assessment by material experts includes aspects assessed by material experts (concept correctness, material composition, assessment, and science process skills). At the end of the assessment, the material expert provides criticism and suggestions on the physics module that was developed so that errors, deficiencies, and incorrect writing of concepts in the module can be corrected and perfected. Based on the results of the product assessment calculation, the Newton's Law module developed is in very good criteria. Based on expert criticism and suggestions, the material listed is used as revision 
material to correct existing errors and deficiencies. Thus, the discovery learning-based physics learning module was changed (revised) by suggestions and criticisms from material experts. The comments from experts can help to enhance the module.

Assessment by physics teachers includes aspects assessed by high schools physics teachers, namely the quality of material content, illustrations (pictures, tables, and concept maps), language, appearance, assessment, science process skills, module completeness, and implementation. At the end of the assessment, the teacher provides criticism and suggestions on the physics module developed. Criticisms and suggestions by the teacher include the use of the word students replaced by students and experiments on Newton's Second Law and Newton's Third Law cannot be carried out by students at home so that other experiments can be substituted using tools around students. Based on the teacher's criticisms and suggestions, the notes are used as revision material to correct existing errors and deficiencies. The results of the assessment by the teacher get the criteria that the module is very good.

\section{Students' Responses in Limited Trial}

Student responses were obtained from a limited test using 11 statements. A limited trial was conducted to obtain student responses to the discovery learning-based physics learning module on Newton's Law material that had been developed. A limited trial was conducted on 5 students of class X MIPA SMA YPPK Taruna Bakti Jayapura. Student responses in the limited trial overall obtained an average score of 3.33. Based on the statements presented as a whole, the students gave an agree response. The results of calculating student responses in a limited trial are presented in the Table 4.

Table 5. Students' Responses in Limited Trial of Newton's Law Module

\begin{tabular}{|c|c|c|}
\hline No & Statements & Score \\
\hline 1 & The appearance of the module can foster the spirit of learning & 3.40 \\
\hline 2 & Instructions for using the module are easy to understand & 3.20 \\
\hline 3 & Systematic presentation of material in a systematic and easy to understand & 3.40 \\
\hline 4 & The module is able to make students learn independently & 3.20 \\
\hline 5 & $\begin{array}{l}\text { Examples of questions presented can be understood according to the } \\
\text { material }\end{array}$ & 3.60 \\
\hline 6 & $\begin{array}{l}\text { The competency test presented is easy to understand and can be done } \\
\text { independently }\end{array}$ & 3.00 \\
\hline 7 & The images presented add to the understanding of the material & 3.60 \\
\hline 8 & The arrangement of words and sentences is easy to understand & 3.20 \\
\hline & Mean Score of Students' Responses & 3.33 \\
\hline
\end{tabular}

After the product is repaired then retested to obtain effective results (Amar et al., 2020). In this activity, researchers conducted a limited trial. A limited trial was conducted to obtain student responses to the discovery learning-based physics learning module on Newton's Law material that had been developed. It measured the readability and feasibility of the electronic module before being used by other classes or students. This is in line with the previous research that developed physics module (Dwi, Andra, \& Distrik, 2019; Sihalolo, Rosidin, \& Suyatna, 2019). Limited testing in the development of module can help to revise the module based on students' ability to understand the intention of using module during the learning process. 


\section{Students' Responses in Broad Trial}

Student responses were obtained from a limited test using 11 statements. Extensive trials were conducted to obtain student responses to the physics learning module based on discovery learning on Newton's Law material that had been developed and the applicability of the module based on n-gain. A broad trial was conducted on 16 students of class X MIPA SMA YPPK Taruna Bakti Jayapura. The list of students for the limited trial is presented in the appendix. Student responses in the broad trial overall obtained an average score of 3.35. Based on the statements presented as a whole, the students gave an agree response. The results of calculating student responses in a limited trial are presented in the Table 5.

Table 6. Students' Responses in Broad Trial of Newton's Law Module

\begin{tabular}{|c|c|c|}
\hline No & Statements & Score \\
\hline 1 & The appearance of the module can foster the spirit of learning & 3.44 \\
\hline 2 & Instructions for using the module are easy to understand & 3.25 \\
\hline 3 & Systematic presentation of material in a systematic and easy to understand & 3.44 \\
\hline 4 & The module is able to make students learn independently & 3.19 \\
\hline 5 & $\begin{array}{l}\text { Examples of questions presented can be understood according to the } \\
\text { material }\end{array}$ & 3.50 \\
\hline 6 & $\begin{array}{l}\text { The competency test presented is easy to understand and can be done } \\
\text { independently }\end{array}$ & 3.06 \\
\hline 7 & The images presented add to the understanding of the material & 3.63 \\
\hline 8 & The arrangement of words and sentences is easy to understand & 3.31 \\
\hline & Mean Score of Students' Responses & 3.35 \\
\hline
\end{tabular}

The next step of development testing is a product design trial activity on the real target subject in a broad sample. We chose 16 students to implement this module and got their responses after the lesson. During this test, response data, reactions or comments were sought from the target user of the module. After the product is repaired then retested to obtain effective results as we needed to get the n-gain to determine students' improvement in scientific literacy aspect. In this activity, researchers conducted a broad trial. The broad trial is needed to apply the module in wider scope and sequence so that the results are valid and module is ready to use for physics learning, especially in Newton's Law material at other location or school. It is in line with the previous research stating that broad testing in $\mathrm{R} \& \mathrm{D}$ is required to conduct since module needs to be tested through applicable area (Indra et al., 2021; Thaoge, 2021). We would know whether the module is applicable or not using broad testing or wide sample trial by implementing it in the wider area of institution. From the results, it can be seen that mean score of students' responses in broad testing was higher than mean score of students' responses in limited testing. From this finding, it can be said that the revision through experts' comments and students' initial responses has affected the readability, feasibility, and usability of developed Newton's Law module.

\section{The Improvement of Students' Scientific Literacy}

Before the module was implemented to the class X MIPA SMA YPPK Taruna Bakti Jayapura students, the researcher gave students a pretest of Newton's Law with scientific literacy indicators. After the developed module was implemented in broad 
trial, the 16 students were also given a posttest of Newton's Law with scientific literacy indicators. Then, the normalized gain value (n-gain) was calculated to determine the improvement of students' scientific literacy at online learning during covid-19 pandemic in Jayapura. N-gain of students' scientific literacy can be seen from Figure 3.

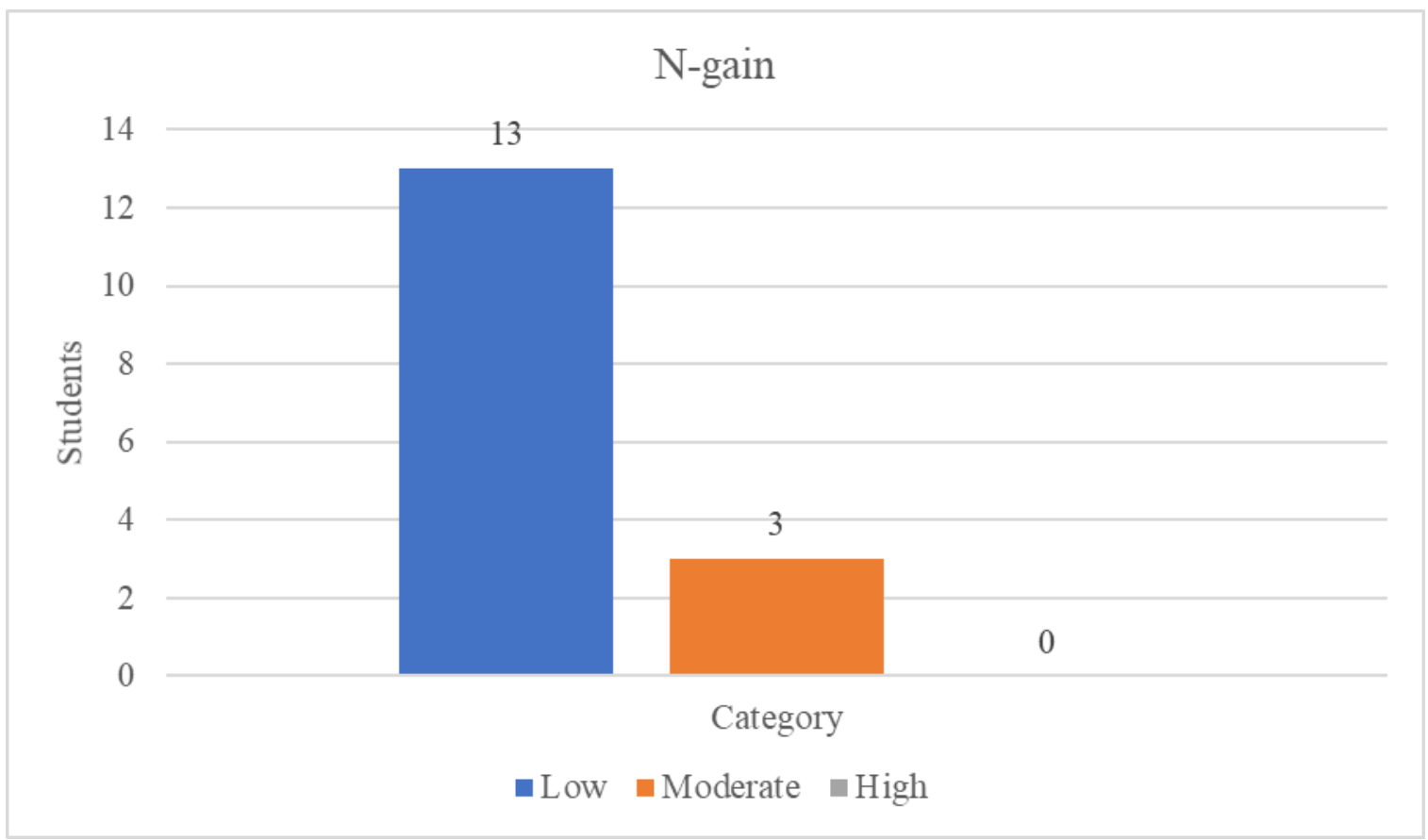

Figure 4. N-gain of Students' Scientific Literacy

From Figure 3, students who have low scientific literacy were 13 and students who have moderate scientific literacy were 3 . There were no students who have high scientific literacy. it can be said that the module cannot significantly improve students' scientific literacy as the students have low score of n-gain in major. It is in line with the previous research related to electronic module in physics learning. Saudi Arabia has developed several learning materials and tools so that students can elaborate their study when they stay at home. It turned out that module has weak influence in students' learning outcomes (Alsmadi et al., 2021). Physics needs to stimulates students' thinking skills and ability (Budiarti, Suparmi, Sarwanto, Harjana, \& Viyanti, 2019). The learning method that is suitable for students is experiment using laboratory tools and media (Manalu, Wanda, Worumboy, \& Budiarti, 2021; Maryam, 2021; Schuchter, 2021). Thus, the module of Newton's Law is expected to be more suitable when the learning is not online but offline. The future research will implement the module during online lesson for Newton's Law material in physics learning.

\section{CONCLUSION}

The researcher conducted a study to produce a product in the form of a science e-module with Newton's Law material based on the discovery learning model to be able to improve students' scientific literacy skills. The purpose of our research was to design a discovery learning-based module to improve scientific literacy skills in Newton's Law 
material and test the quality to get student responses in class X SMA YPPK Taruna Bakti. Validator 1 states that the presentation of sentence editorials on achievement indicators needs to be adjusted to learning outcomes and operational verbs. The presentation of concept maps needs to be adjusted to the physical meaning (full explanation is in the draft). Evaluation presentations should avoid statements that are too long because the representation of students in the class varies. From six validation statements, there were two points that needed revision. It can be seen that mean score of students' responses in broad testing was higher than mean score of students' responses in limited testing. The revision through experts' comments and students' initial responses has affected the readability, feasibility, and usability of developed Newton's Law module. Students who have low scientific literacy were 13 and students who have moderate scientific literacy were 3 . There were no students who have high scientific literacy. It can be said that the module cannot significantly improve students' scientific literacy as the students have low score of n-gain in major. The provision of lack improvement also can be caused by the online learning environment.

\section{ACKNOWLEDGEMENTS (OPTIONAL)}

The researchers want to acknowledge Universitas Cenderawasih for their support, grant, and permission to conduct this research. The researcher also want to thank the teachers and students at SMA YPPK Taruna Bakti Jayapura for the time and permission given during the research to assist and join the data collection.

\section{REFERENCES}

Abou Faour, M., \& Ayoubi, Z. (2017). The effect of using virtual laboratory on grade 10 students' conceptual understanding and their attitudes towards physics. Journal Of Education In Science Environment And HEALTH, 4(1), 54-68.

Alsmadi, M. K., Al-Marashdeh, I., Alzaqebah, M., Jaradat, G., Alghamdi, F. A., Mohammad, R. M. A., ... Aldhafferi, N. (2021). Digitalization of learning in Saudi Arabia during the COVID-19 outbreak: A survey. Informatics in Medicine Unlocked, 100632.

Amar, G. I., Suranto, S., \& Sajidan, S. (2020). The Use of a Creative Problem Solving Based Genetic Mutation Module in Higher Education. International Journal of Higher Education, 10(3), 33. https://doi.org/10.5430/ijhe.v10n3p33

Annisa, S. A., Lesmono, A. D., \& Yushardi, Y. (2020). Comic-Based Module Development Andro-Web to Improve Problem Solving Ability in Physics in High School Students. Berkala Ilmiah Pendidikan Fisika, 8(1), 40. https://doi.org/10.20527/bipf.v8i1.7641

Bai, Y., Yao, L., Wei, T., Tian, F., Jin, D.-Y., Chen, L., \& Wang, M. (2020). Presumed Asymptomatic Carrier Transmission of COVID-19. JAMA. https://doi.org/10.1001/jama.2020.2565

Basu, S., Biswas, G., \& Kinnebrew, J. S. (2017). Learner modeling for adaptive scaffolding in a computational thinking-based science learning environment. User Modeling and User-Adapted Interaction, 27(1), 5-53. 
Buchori, A., \& Setyawati, R. D. (2015). Development learning model of charactereducation through e-comic in elementary school. International Journal of Education and Research, 3(9), 369-386.

Budiarti, I. S. B., Suparmi, S., Sarwanto, S., Harjana, H., \& Viyanti, V. (2019). Stimulating Students' Higher-Order Thinking Skills on Heat and Temperature Concepts. Jurnal Pembelajaran Fisika, 7(2), 77-85.

Buheji, M., \& Buheji, A. (2020). Planning Competency in the New NormalEmployability Competency in Post-COVID-19 Pandemic. International Journal of Human Resource Studies, 10(2), 237-251.

Çelik, A., Yaman, H., Turan, S., Kara, A., Kara, F., Zhu, B., ... Dutta, D. (2018). No 主観的健康感を中心とした在宅高齢者における 健康関連指標に関する共分散構造分析Title. In Journal of Materials Processing Technology (Vol. 1). Retrieved from http://dx.doi.org/10.1016/j.cirp.2016.06.001\%0Ahttp://dx.doi.org/10.1016/j.pow tec.2016.12.055\%0Ahttps://doi.org/10.1016/j.ijfatigue.2019.02.006\%0Ahttps://d oi.org/10.1016/j.matlet.2019.04.024\%0Ahttps://doi.org/10.1016/j.matlet.2019.1 27252\%0Ahttp://dx.doi.o

Dwi Kurniati, R., Andra, D., \& Distrik, I. W. (2019). The Role of Social Media in Learning Physics: Teacher and Student Perceptions. Jurnal Pembelajaran Fisika, 8(2), 159-166. https://doi.org/10.23960/jpf.v8.n2.202004

Fajrillah, F., Sulaiman, O. K., Abi Hamid, M., Simanihuruk, L., Simarmata, J., Hasibuan, M. S., ... Guci, D. A. (2020). MOOC: Platform Pembelajaran Daring di Abad 21. Yayasan Kita Menulis.

Fitriyani, Y., Fauzi, I., \& Sari, M. Z. (2020). Motivasi Belajar Mahasiswa Pada Pembelajaran Daring Selama Pandemik Covid-19. Jurnal Kependidikan: Jurnal Hasil Penelitian Dan Kajian Kepustakaan Di Bidang Pendidikan, Pengajaran Dan Pembelajaran, 6(2), 165-175.

Hadi, W. P., Munawaroh, F., Rosidi, I., \& Wardani, W. K. (2020). Penerapan Model Pembelajaran Discovery Learning Berpendekatan Etnosains untuk Mengetahui Profil Literasi Sains Siswa SMP. Jurnal IPA \& Pembelajaran IPA, 4(2), 178192. https://doi.org/10.24815/jipi.v4i2.15771

Hall, D. M., \& Steiner, R. (2020). Policy content analysis: Qualitative method for analyzing sub-national insect pollinator legislation. MethodsX, 7, 100787. https://doi.org/10.1016/j.mex.2020.100787

Hartini, S., Firdausi, S., Misbah, M., \& Sulaeman, N. F. (2018). The development of physics teaching materials based on local wisdom to train saraba kawa character. Jurnal Pendidikan IPA Indonesia, 7(2), 130-137.

Indarti, S. (2019). Investigasi Implementasi Model Discovery Learning Berbasis Pendekatan Saintifik Dalam Meningkatkan Aktivitas dan Hasil Belajar IPA. IJIS Edu: Indonesian Journal of Integrated Science Education, 1(2), 100. https://doi.org/10.29300/ijisedu.v1i2.2244 
Indra, I., Astuti, I., \& Mering, A. (2021). PENGEMBANGAN e-MODUL TEMATIK UNTUK PEMBELAJARAN KELAS IV SEKOLAH DASAR. Jurnal Pendidikan Dan Pembelajaran Khatulistiwa, 10(6).

Kompas. (n.d.). Rangkaian Peristiwa Pertama Covid-19 - Bebas Akses. Retrieved May 15, 2020, from https://bebas.kompas.id/baca/riset/2020/04/18/rangkaianperistiwa-pertama-covid-19/

Kurniawan, W., Jufrida, J., Basuki, F. R., Ariani, R., \& Fitaloka, O. (2019). Virtual Laboratory Based Guided Inquiry: Viscosity Exsperiments. JIPF (Jurnal Ilmu Pendidikan Fisika), 4(2), 91. https://doi.org/10.26737/jipf.v4i2.1069

Li, J., Ye, H., Tang, Y., Zhou, Z., \& Hu, X. (2018). What Are the Effects of SelfRegulation Phases and Strategies for Chinese Students? A Meta-Analysis of Two Decades Research of the Association Between Self-Regulation and Academic Performance . Frontiers in Psychology , Vol. 9, p. 2434. Retrieved from https://www.frontiersin.org/article/10.3389/fpsyg.2018.02434

Manalu, A. N., Wanda, Y. A., Worumboy, H. V. N., \& Budiarti, I. S. (2021). Digital Literacy Overview: Challenges in Online Physics Learning at New Normal Era. $\begin{array}{llll}\text { Berkala Ilmiah Pendidikan Fisika, } & \end{array}$ https://doi.org/10.20527/bipf.v9i1.9367

Maryam, E. M. E. (2021). Penggunaan Layanan Aplikasi Google Classroom Untuk Meningkatkan Hasil Belajar Fisika Mahamahasiswa Universitas Bina Insan. Journal of Education and Culture, 1(1).

MASKHULIAH, P., \& BUNGKANG, Y. (2017). Pengembangan Modul Pembelajaran IPA Berbasis Pendekatan Keterampilan Proses Sains Pada Materi Listrik Dinamis Untuk Siswa Kelas IX Mts Al Muttaqin Buper Jayapura. Jurnal Ilmu Pendidikan Indonesia, 5(1), 55-66.

Medvedev, O. N., Siegert, R. J., Mohamed, A. D., Shepherd, D., Landhuis, E., \& Krägeloh, C. U. (2017). The Oxford Happiness Questionnaire: transformation from an ordinal to an interval measure using Rasch analysis. Journal of Happiness Studies, 18(5), 1425-1443.

Merta Dhewa, K., Rosidin, U., Abdurrahman, A., \& Suyatna, A. (2017). The development of Higher Order Thinking Skill (Hots) instrument assessment in physics study. IOSR Journal of Research \& Method in Education (IOSR-JRME), 7(1), 26-32.

Mustari, M., \& Sari, Y. (2017). Pengembangan media gambar berupa buku saku Fisika SMP pokok bahasan suhu dan kalor. Jurnal Ilmiah Pendidikan Fisika Al-Biruni, 6(1), 113-123.

Naimah, J., Winarni, D. S., \& Widiyawati, Y. (2019). Pengembangan Game Edukasi Science Adventure Untuk Meningkatkan Keterampilanpemecahan Masalah Siswa. Jurnal Pendidikan Sains Indonesia (Indonesian Journal of Science Education), 7(2), 91-100. https://doi.org/10.24815/jpsi.v7i2.14462

Nomor, P. (22 C.E.). Tahun 2016, Standar proses untuk. Satuan Pendidikan Dasar Dan Menengah, Jakarta, Kemdikbud. 
OECD. (2016). PISA 2015 Assessment and Analytical Framework PISA 2015 Assessment and Analytical Framework. In OECD Publishing. Retrieved from https://www.oecd-ilibrary.org/docserver/9789264190511en.pdf?expires=1569847112\&id=id\&accname=guest\&checksum=08AEA3FD 9 105123D4555A383BD097B5E

OECD, Assessment, D. P. for I. S., Econòmic, O. de C. i D., IVEI., I., OCSE., Staff, O., ... PISA. (2004). PISA Learning for Tomorrow's World: First Results from PISA 2003 (Vol. 659). Simon and Schuster.

Rahayu, P., T RUMAHORBO, B., \& Wahyudi, I. (2020). PENGEMBANGAN MODUL IPA BERBASIS DISCOVERY LEARNING DALAM MENINGKATKAN, KETRAMPILAN PROSES, PESERTA DIDIK PADA MATERI GETARAN, GELOMBANG, DAN BUNYI. Jurnal Ilmu Pendidikan Indonesia, 8(2), 95-102.

Rianti, S., Akhsan, H., \& Ismet, I. (2020). Development Modern Physics Digital Handout Based on Technology Literacy. Berkala Ilmiah Pendidikan Fisika, 8(1), 23. https://doi.org/10.20527/bipf.v8i1.7593

Risdianto, E., Dinissjah, M. J., \& Nirwana, M. K. (2020). The Effect of Ethno ScienceBased Direct Instruction Learning Model in Physics Learning on Students' Critical Thinking Skill. Universal Journal of Educational Research, 8(2), 611615.

Rosanna, D. L., Yerimadesi, A., \& Oktavia, B. (2021). Validity and Practicality of Salt Hydrolysis E-Module Based on Guided Discovery Learning for SMA/MA Students.

Sadikin, A., \& Hamidah, A. (2020). Pembelajaran Daring di Tengah Wabah Covid-19. Biodik, 6(2), 214-224.

Saputra, H., Al Auwal, T. M. R., \& Mustika, D. (2017). Pembelajaran Inkuiri Berbasis Virtual Laboratory Untuk Meningkatkan Kemampuan Literasi Sains Mahasiswa Calon Guru Pendidikan Fisika Universitas Samudra. Jurnal IPA \& Pembelajaran IPA, 1(2), 143-148. https://doi.org/10.24815/jipi.v1i2.9688

Schuchter, A. (2021). Co-creational Education: A Project-based Flipped Classroom Workshop Series for Online Education using Drone Building to Teach Engineering Subjects. CSEDU (1), 447-457.

Serway, R. A., \& Jewett, J. W. (1998). Principles of physics (Vol. 1). Saunders College Pub. Fort Worth, TX.

Sihalolo, Y. E. M., Rosidin, U., \& Suyatna, A. (2019). Jurnal pembelajaran fisika. Jurnal Pembelajaran Fisika, 7(2), 77-85.

Sohn, S. Y., \& Yoon, K. B. (2010). Dynamic preventive maintenance scheduling of the modules of fighter aircraft based on random effects regression model. Journal of the Operational Research Society, 61(6), 974-979. 
Sudarmin, S., Mursiti, S., \& Asih, A. G. (2018). The use of scientific direct instruction model with video learning of ethnoscience to improve students' critical thinking skills. Journal of Physics: Conference Series, 1006(1), 12011.

Sugiyono, D. (2010). Metode penelitian kuantitatif dan R\&D. Bandung: Alfabeta.

Thaoge, M. L. (2021). A proposed framework for designing an online based (Elearning) Work Integrated Learning (WIL) module for the Diploma in Biotechnology.

Trianggono, M. M. (2017). Analisis Kausalitas Pemahaman Konsep Dengan Kemampuan Berpikir Kreatif Siswa Pada Pemecahan Masalah Fisika.

Trianto, I. B. (2014). Mendesain Model Pembelajaran Inovatif, Progresif, dan Konstektual: Konsep, Landasan, dan Implementasi pada Kurikulum 2013. Jakarta: Kencana.

Wartono, W., Batlolona, J. R., \& Mahfi, R. M. (2019). PENINGKATAN KEMAMPUAN PEMECAHAN MASALAH FISIKA DENGAN MODEL PEMBELAJARAN INQUIRY-DISCOVERY. EDUSAINS, 11(2), 242-248. 